\title{
Passive immunity transfer and serum constituents of crossbred calves ${ }^{1}$
}

\author{
Thaís G. Rocha ${ }^{2 *}$, Ricardo P. Nociti ${ }^{3}$, Alexandre A.M. Sampaio ${ }^{4}$ \\ and José Jurandir Fagliari ${ }^{5}$
}

\begin{abstract}
Rocha T.G., Nociti R.P., Sampaio A.A.M. \& Fagliari J.J. 2012. Passive immunity transfer and serum constituents of crossbred calves. Pesquisa Veterinária Brasileira 32(6):515-522. Departamento de Clínica e Cirurgia Veterinária, Faculdade de Ciências Agrárias e Veterinárias, Universidade Estadual Paulista Julio de Mesquita Filho, Campus de Jaboticabal, Via de Acesso Prof. Paulo Donato Castellane s/n, Jaboticabal, SP 14884-900, Brazil. E-mail: thaisgrocha@yahoo.com.br

Passive immunity transfer (PIT) evaluation is an essential tool for the maintenance of healthy calves during the first months of life. Since lactation number and breed have been proven to influence immunoglobulin levels in colostrum, the aim of this study was to evaluate PIT from primiparous and multiparous Canchim cows to their calves. Blood samples were collected from the calves before colostrum intake and 1, 2, 7, 15 and 30 days thereafter, while colostrum samples from the cows were taken immediately after parturition. Activities of gamma-glutamyl transferase (GGT), alkaline phosphatase (ALP), and concentrations of total protein, albumin, globulins, immunoglobulin A (IgA), immunoglobulin G (IgG), total and ionized calcium, inorganic phosphorus, magnesium, sodium and potassium were evaluated in calves' serum and activities of GGT and ALP and concentrations of total protein, IgA and IgG were assessed in cow's colostrum whey. Immunoglobulins concentrations were evaluated by electrophoresis in polyacrylamide gels. Serum biochemistry evaluations revealed an increase in gamma-glutamyl transferase and alkaline phosphatase activities and in total protein, globulins, immunoglobulin A and immunoglobulin G levels in calves' serum after colostrum intake. Only total protein and light chain immunoglobulin G levels in colostrum whey were affected by the cows' lactation number. Phosphorus and magnesium levels in blood serum increased after colostrum intake, while sodium and potassium levels oscillated in the experimental period. PIT was influenced by the cows' lactation number but was efficient in both groups.
\end{abstract}

INDEX TERMS: Beef cattle, colostrum, serum constituents, immunoglobulins, SDS-PAGE.

RESUMO.- [Transferência de imunidade passiva e constituintes séricos de bezerros mestiços.] A avaliação da transferência de imunidade passiva (TIP) é uma ferramen-

\footnotetext{
${ }^{1}$ Received on November 3, 2011.

Accepted for publication on February 14, 2012.

${ }^{2}$ Pós-Graduanda do curso de Medicina Veterinária (Clínica Médica Veterinária), FCAV-Unesp/Campus de Jaboticabal, Av. General Carneiro 460, apto 42, Centro, Jaboticabal, SP 14870-040, Brazil. *Corrersponding author: thaisgrocha@yahoo.com.br

${ }^{3}$ Médico Veterinário Autônomo. E-mail: rnociti@gmail.com

${ }^{4}$ Docente do Departamento de Zootecnia, FCAV-Unesp/Campus de Jaboticabal, Via de Acesso Prof. Paulo Donato Castellane s/n, Jaboticabal, SP 14884-900. E-mail: sampaio@fcav.unesp.br

${ }^{5}$ Docente do Departamento de Clínica e Cirurgia Veterinária, FCAV-Unesp, Jaboticabal, SP. E-mail: fagliari@fcav.unesp.br
}

ta essencial para manutenção de bezerros saudáveis nos primeiros meses de vida. Uma vez que há influência do número de lactações e da raça de vacas nos teores de imunoglobulinas do colostro, o presente estudo foi conduzido com o objetivo de avaliar a TIP de vacas Canchim primíparas e pluríparas aos seus bezerros. Amostras de sangue dos bezerros foram coletadas antes da ingestão de colostro e 1 , $2,7,15$ e 30 dias após o nascimento e amostras de colostro das vacas foram coletadas imediatamente após o parto. As atividades de gamaglutamiltransferase (GGT), fosfatase alcalina (ALP) e as concentrações de proteína total, albumina, globulinas, imunoglobulina A (IgA) e imunoglobulina G (IgG), cálcio total e ionizado, fósforo, magnésio, sódio e potássio foram avaliadas no soro dos bezerros e as atividades de GGT e ALP e as concentrações de proteína total, IgA 
e IgG foram avaliadas no soro colostral. A concentração de imunoglobulinas foi avaliada por meio de eletroforese em gel de poliacrilamida. As avaliações bioquímicas do soro sanguíneo dos bezerros revelaram aumento nas atividades das enzimas gamaglutamiltransferase e fosfatase alcalina e nos teores de proteína total, globulinas, imunoglobulina A e imunoglobulina $\mathrm{G}$ após a ingestão do colostro. Apenas os teores de proteína total e imunoglobulina G de cadeia leve no soro colostral foram influenciados pelo número de lactações das vacas. Os teores de fósforo e magnésio aumentaram após a ingestão de colostro, enquanto as concentrações de sódio e potássio oscilaram no decorrer do período experimental. A TIP foi influenciada pelo número de lactações das vacas, no entanto mostrou-se eficiente em ambos os grupos.

TERMOS DE INDEXAÇÃO: Bovinos de corte, colostro, constituintes séricos, imunoglobulinas, SDS-PAGE.

\section{INTRODUCTION}

Diarrhea and respiratory disease problems are the most important infirmities of neonatal calves, causing the greatest economic loss in this age group in both dairy and beef herds (Barrington et al. 2002, Callan \& Gary 2002). Neonatal calves need maternal immunological assistance in the first hours after birth, provided by colostrum intake, since they have a higher likelihood of succumbing to infections that are innocuous to adult animals, so neonates that suffer failure of passive transfer of maternal immunoglobulins may be at increased risk for disease (Barrington \& Parish 2001).

The importance of colostrum intake has been studied exhaustively and it has been known for more than a century that resistance to specific diseases occurs through colostrum intake. It is widely recognized that maternal immunoglobulins, immune cells and various cytokines are supplied to the neonate through colostrum because the syndesmochorial structure of the ruminant placenta prevents prepartum transfer, so calves are born agammaglobulinemic or significantly hypogammaglobulinemic (Fagliari et al. 1986, Barrington \& Parish 2001).

The failure of passive immune transfer (FPIT) of colostrum immunoglobulins is as high in dairy calves that suckle from their dams as it is in those that receive bottled colostrum, but is lower in beef calves (Radostits et al. 2007). This difference may be due to the influence of breed on colostrum quality. Some studies have found that beef cows produce colostrum with a higher content of immunoglobulins than dairy breeds (Besser \& Gay 1994, Guy et al. 1994, Godden 2008). These differences may be due to the smaller volume of colostrum and the selective capacity of secretory cells to transport immunoglobulin G (IgG) from blood to mammary secretions in beef cows (Pritchett et al. 1991, Costa et al. 2008).

Greater calf vigor and a higher concentration of immunoglobulins in the colostrum of beef cows allow for the intake of a smaller amount of colostrum to provide the concentration of immunoglobulins necessary for the protection of beef calves in the first months of life. However, the volume of colostrum and the immunoglobulin concentration may vary widely in beef cows, especially in primiparous ones (Radostits et al. 2007).

There are many methods to quantitate the immunoglobulin concentration in calf serum after colostrum intake. The total protein level is an indirect but reliable way to evaluate the concentration of absorbed IgG (Borges et al. 2001). Serum protein levels below $4.2 \mathrm{~g} / \mathrm{dL}$ are considered highly sensitive and specific for the detection of FPIT (Feitosa et al. 2001). Gamma-glutamyl tranferase (GGT) activity is another way to evaluate indirectly the passive immunity transfer of immunoglobulins to calves. GGT activity in colostrum is high and its serum activity in calves that suckled or were fed colostrum is 60 to 160 times greater than in adult animals, and is correlated significantly with serum concentrations of IgG in calves (Fagliari et al. 1996, Radostits et al. 2007).

Furthermore, knowledge of the changes in the serum biochemical profile of calves, allied to other data obtained from the animals, may be useful for establishing initial baseline parameters for a patient, formulating a problem or rule-out list, confirming a diagnosis, determining the prognosis, planning therapeutic options, and monitoring response to treatment (Russel \& Roussel 2007).

The aim of this study was to evaluate passive immunity transfer in beef calves born to primiparous or multiparous cows by analyzing the concentrations of alkaline phosphatase, gamma-glutamyl transferase, total protein, albumin, globulins, immunoglobulin $A$ and immunoglobulin $G$ in the calves' first month of life, as well as levels of alkaline phosphatase, gamma-glutamyl transferase, total protein, immunoglobulins A and G in cows' whey. Calves' serum concentrations of total and ionized calcium, inorganic phosphorus, magnesium, sodium and potassium were also assessed.

\section{MATERIALS AND METHODS}

Twenty-six healthy crossbred Canchim-Nelore calves were allotted to two experimental groups: group B1, comprising 13 calves born to primiparous cows, and group B2, comprising 13 calves born to multiparous cows (2-7 parturitions). Because colostrum samples from the dams were evaluated, they were also divided into two experimental groups: group V1, comprising 13 primiparous cows, and group V2, comprising 13 multiparous cows. The animals were submitted to clinical examination daily during the experimental period (Dirksen et al 1993). The experimental design was approved by the Animal Ethics Committee of the School of Veterinary Medicine of the São Paulo State University (Unesp) at Jaboticabal, under protocol number 009793-08.

Blood samples were collected from the calves by jugular venipuncture, using Vacutainer ${ }^{\circledR}$ tubes (Vacutainer, Becton Dickinson, Franklin Lakes, NJ, USA) without anticoagulant, before colostrum intake and $1,2,7,15$, and 30 days after birth. The blood was centrifuged at $1.000 \mathrm{x}$ g for 10 minutes, and serum samples were stored at $-18^{\circ} \mathrm{C}$ until analysis.

Colostrum samples $(n=26)$ were collected immediately after parturition. Colostrum whey was obtained by adding $5 \mathrm{ml}$ of rennet (Coalho Estrella $®$, Chr. Hansen Brazil Ind. e Com. Ltda, Valinhos, SP) to $100 \mathrm{ml}$ of colostrum. After stirring and incubation at $37^{\circ} \mathrm{C}$ for $20 \mathrm{~min}$, the whey was separated by centrifugation. Whey samples were then stored at $-20^{\circ} \mathrm{C}$ until analysis. 
Gamma-glutamyl transferase (modified Szasz method), alkaline phosphatase (modified Bowers and McComb method), total protein (biuret method), albumin (bromocresol green method), calcium (CPC reaction), phosphorus (modified Daly and Ertinghausen method), and magnesium (Labtest reaction) concentrations were then determined spectrophotometrically in serum samples, using commercial reagents (Labtest Diagnostica, Lagoa Santa, Minas Gerais, Brazil). Ionized calcium, sodium and potassium levels were determined by the ion-selective electrode method (9180 Electrolyte Analyzer, Roche Diagnostics, Mannheim, Germany). The same methodology was used for the evaluation of gamma-glutamyl transferase, alkaline phosphatase, and total protein concentrations in colostrum whey of cows. Whenever necessary, the whey samples were diluted in deionized water as follows: gamma-glutamyl transferase: day $0=1: 150$; total protein: day $0=1: 3$. Serum samples were also diluted for determination of GGT activity as follows: day $0=1: 20$; days $1-2=1: 10$.

Serum concentrations of globulins were calculated arithmetically based on the difference between total protein and albumin concentrations in serum.

Electrophoretic separation of serum and whey proteins was carried out in polyacrylamide gels using the technique described by Laemmli (1970). After separation of protein fractions, the gel was colored in a $0.2 \%$ coomassie blue solution. Concentration of protein fractions was determined by use of computer assisted densitometry (Shimadzu CS9301, Tokyo, Japan). Reference markers (Sigma, St Louis, MO, USA) with molecular weights of $24 \mathrm{kDa}, 29 \mathrm{kDa}, 36 \mathrm{kDa}$, $45 \mathrm{kDa}, 55 \mathrm{kDa}, 66 \mathrm{kDa}, 97 \mathrm{kDa}, 116 \mathrm{kDa}$, and $205 \mathrm{kDa}$ were used to identify protein fractions associated with comparison with the electrophoretic mobility of purified immunoglobulin A, and immunoglobulin G (light chain and heavy chain). From up to 29 protein fractions identified in calves' serum and up to 16 protein fractions identified in colostrum whey, only immunoglobulins A and G were analyzed to determine passive immunity transfer.

The data were analyzed by ANOVA and the differences among groups were compared by the Tukey test. Pearson's correlation test was also used and differences were considered significant at $P<0.05$ in both tests (Zar 1999). Correlations above 0.50 were considered strong; between 0.30 and 0.49 were considered medium and below 0.29 were considered small.

\section{RESULTS AND DISCUSSION}

None of the calves in the experimental groups B1 and B2 presented any abnormalities such as diarrhea or pneumonia in the first 30 days of life.

Serum activities of alkaline phosphatase (ALP) and gamma-glutamyl transferase (GGT) after colostrum intake were higher in group B1 than in group B2 (Table 1). In both groups the serum activity of ALP at birth was within the limits reported for cattle (Kaneko et al. 2008) (Table 6). However, after colostrum intake, these levels rose 2 and 1.5fold above the reference values in adult animals in groups B1 and B2, respectively, which is consistent with the findings of Knowles et al. (2000), who described an increase of four times the upper limit of the reference range in newborn calves when compared to adults. Zanker et al. (2001) found an initial, transient rise in ALP activity in calves fed first colostrum at 0-2 hours after birth when compared to calves fed first colostrum at 12-13 and 24-25 hours after birth. They attributed this increase to absorption of ALP from colostrum or to an enhanced endogenous production of this enzyme.

The absorption of GGT from colostrum in the first hours after birth increased the activity of this enzyme in the calves' serum 199-fold in Group B1 and 111-fold in Group B2. These results are similar to those reported by Ježek et al. (2006) for dairy calves. It is likely that the higher volume of colostrum produced by multiparous cows worked as a dilution factor for this enzyme activity, which would justify its higher activity in the serum samples of group B1. Contrary to our findings, Feitosa et al. (2010) reported higher GGT activity in the serum of Nelore calves born to multiparous cows $(2,398 \pm 2,077 \mathrm{U} / \mathrm{L})$ than in calves born to primiparous ones $(1,911 \pm 2,336 \mathrm{U} / \mathrm{L})$. In Holstein calves, however, these authors reported higher activity of GGT in serum of calves born to primiparous cows $(774 \pm 549 \mathrm{U} / \mathrm{L})$ than multiparous cows $(673 \pm 449 \mathrm{U} / \mathrm{L})$, which agrees with our results.

Table 1. Mean and standard deviation of enzymes and proteins in blood serum of Canchim-Nelore calves born to primiparous (B1) and multiparous (B2) cows before colostrum intake $(0)$ and after $1,2,7,15$, and 30 days of life

\begin{tabular}{ccccccc}
\hline Group & \multicolumn{5}{c}{ Moments (days) } \\
\cline { 2 - 7 } & 0 & 1 & 2 & 7 & 15 \\
\hline & & \multicolumn{5}{c}{ Alkaline phosphatase (U/L) } \\
B1 & $307 \pm 63.3 \mathrm{Ad}$ & $1,030 \pm 415 \mathrm{Aa}$ & $434 \pm 112 \mathrm{Acd}$ & $614 \pm 160 \mathrm{Abc}$ & $690 \pm 188 \mathrm{Ab}$ & $620 \pm 208 \mathrm{Abc}$ \\
B2 & $351 \pm 184 \mathrm{Ab}$ & $746 \pm 272 \mathrm{Ba}$ & $365 \pm 104 \mathrm{Ab}$ & $408 \pm 153 \mathrm{Bb}$ & $444 \pm 124 \mathrm{Bb}$ & $535 \pm 139 \mathrm{Aab}$ \\
\multicolumn{5}{c}{ Gamma-glutamyl transferase (U/L) } \\
B1 & $18.8 \pm 5.05 \mathrm{Ac}$ & $3,746 \pm 1,522 \mathrm{Aa}$ & $1,889 \pm 987 \mathrm{Ab}$ & $651 \pm 336 \mathrm{Ac}$ & $217 \pm 92.1 \mathrm{Ac}$ & $54.7 \pm 15.3 \mathrm{Ac}$ \\
B2 & $25.9 \pm 9.66 \mathrm{Ac}$ & $2,881 \pm 1,644 \mathrm{Ba}$ & $1,414 \pm 868 \mathrm{Ab}$ & $484 \pm 272 \mathrm{Ac}$ & $187 \pm 100 \mathrm{Ac}$ & $62.4 \pm 20.7 \mathrm{Ac}$ \\
& \multicolumn{5}{c}{ Total protein (g/dL) } \\
B1 & $3.98 \pm 0.27 \mathrm{Ac}$ & $6.78 \pm 0.88 \mathrm{Ba}$ & $6.88 \pm 0.90 \mathrm{Ba}$ & $6.58 \pm 0.85 \mathrm{Bab}$ & $6.37 \pm 0.54 \mathrm{Aab}$ & $6.05 \pm 0.40 \mathrm{Ab}$ \\
B2 & $4.26 \pm 0.25 \mathrm{Ae}$ & $7.75 \pm 1.06 \mathrm{Aab}$ & $7.77 \pm 1.12 \mathrm{Aa}$ & $7.23 \pm 0.89 \mathrm{Abc}$ & $6.85 \pm 0.65 \mathrm{Ac}$ & $6.30 \pm 0.40 \mathrm{Ad}$ \\
\multicolumn{5}{c}{ Albumin $(\mathrm{g} / \mathrm{dL})$} \\
B1 & $2.04 \pm 0.22 \mathrm{Ac}$ & $1.67 \pm 0.24 \mathrm{Ad}$ & $1.77 \pm 0.21 \mathrm{Ad}$ & $2.12 \pm 0.25 \mathrm{Ac}$ & $2.40 \pm 0.18 \mathrm{Ab}$ & $2.67 \pm 0.14 \mathrm{Aa}$ \\
B2 & $2.12 \pm 0.17 \mathrm{Ac}$ & $1.74 \pm 0.18 \mathrm{Ad}$ & $1.86 \pm 0.21 \mathrm{Ad}$ & $2.14 \pm 0.17 \mathrm{Ac}$ & $2.43 \pm 0.17 \mathrm{Ab}$ & $2.72 \pm 0.22 \mathrm{Aa}$ \\
& & \multicolumn{5}{c}{ Globulins (g/dL) } \\
B1 & $1.94 \pm 0.25 \mathrm{Ad}$ & $5.11 \pm 0.94 \mathrm{Ba}$ & $5.10 \pm 0.96 \mathrm{Ba}$ & $4.46 \pm 0.82 \mathrm{Bb}$ & $3.97 \pm 0.56 \mathrm{Ab}$ & $3.38 \pm 0.31 \mathrm{Ac}$ \\
B2 & $2.14 \pm 0.36 \mathrm{Ae}$ & $6.01 \pm 1.14 \mathrm{Aa}$ & $5.91 \pm 1.24 \mathrm{Aa}$ & $5.09 \pm 0.96 \mathrm{Ab}$ & $4.42 \pm 0.75 \mathrm{Ac}$ & $3.58 \pm 0.52 \mathrm{Ad}$
\end{tabular}

Mean values followed by the same upper case letters in the same column and lower case letters on the same line do not differ significantly according to Tukey test $(\mathrm{P}<0.05)$. 
No differences were found in ALP or GGT activities in colostrum whey of V1 and V2 cows (Table 4). Zanker et al. (2001) reported ALP and GGT activities of 1,168 U/L and $30,479 \mathrm{U} / \mathrm{L}$, respectively, in colostrum whey of cows up to 2 hours after parturition. According to these authors, whey GGT activity is very high immediately after parturition, declining gradually over the subsequent days. Hoffmann \& Solter (2008) reported that GGT is absorbed passively from colostrum whey by neonates and can be used as an easy and reliable method to assess the efficiency of passive immunity transfer in this species, as ratified by our results.

Serum levels of total protein and globulins were higher in Group B2 after colostrum intake than in group B1 (Table 1). Total protein levels in serum at birth were lower than reference values for cattle in both groups (Kaneko et al. 2008) (Table 6), which is consistent with the findings of Knowles et al. (2000) who reported that concentrations of total protein were approximately $1 \mathrm{~g} / \mathrm{dL}$ below the lower limit of reference range at birth. There were no low values of total protein or globulin levels in either of the experimental groups after natural intake of colostrum. Contrary to our findings, Costa et al. (2008) did not detect any influence of parturition number in the total protein and globulin levels of Nelore and Limousin calves. However, Feitosa et al. (2010) reported that Holstein calves born to multiparous cows presented higher levels of total protein in serum $(6.45 \pm 1.25 \mathrm{~g} / \mathrm{dL})$ than calves born to primiparous cows $(6.06 \pm 1.18 \mathrm{~g} / \mathrm{dL})$. The difference between groups observed in our study did not reflect an inability of primiparous cows to produce an adequate volume and quality of colostrum for their offspring.

Serum levels of total protein were strongly correlated with serum activity of GGT ( $\mathrm{r}=0.52, \mathrm{P}<0.01)$, and globulins $(\mathrm{r}=0.97, \mathrm{P}<0.01)$ (Table 5). The correlation between GGT activity and serum concentration of globulins was also strong $(\mathrm{r}=0.62, \mathrm{P}<0.01)$ (Table 5) and very close to the values reported by Fagliari et al. (1996), confirming that total protein levels and GGT activity are reliable indicators of PIT in calves.
Albumin concentrations did not differ between groups (Table 1). A decline in serum albumin levels in the first two days of life had already been reported by Kurz \& Willett (1991); after these moments, the mean concentration of albumin increased slowly from birth to 30 days of age in both groups, which was also reported by Knowles et al. (2000) and Ježek et al. (2006).

Total whey protein levels in group V2 cows were higher than in group V1 (Table 4). The total protein concentration in colostrum whey was similar to that reported by Sant'ana (2004). Zarcula et al. (2010) reported that the cow's breed, parity, feed intake and yield production influence the chemical composition of first colostrum. According to these authors, the lower the yield of milk the better its chemical composition, which is contrary to our findings in regards to protein concentration.

The total protein content of first colostrum whey from V1 and V2 cows presented a strong correlation to total protein $(\mathrm{r}=0.53 ; \mathrm{P}<0.01)$ and a medium correlation to total IgG $(\mathrm{r}=0.41 ; \mathrm{P}<0.05)$ in the blood serum of B1 and B2 calves, respectively, 24 hours after birth (Table 5).

The electrophoretic separation of serum proteins revealed a higher concentration of immunoglobulin $\mathrm{A}(\operatorname{IgA})$ in group B2 calves than in group B1 after colostrum intake, although the difference was not statistically significant. Statistical differences were noted only at 7 and 30 days of age, and serum levels of IgA increased gradually, with maximum concentrations found at 15 days (Table 2). The concentration of this protein in group B2 was similar to that reported by Hurley (2003).

Although not statistically different, the IgA concentration in the colostrum whey of group V2 cows was higher (Table 4), which may explain the difference in the concentration of this protein in the calves' blood serum. Kehoe et al. (2007), who used the radial immunodiffusion technique, reported much lower IgA levels in the colostrum of Holstein cows than we found in our study $(166 \mathrm{mg} / \mathrm{dL})$ and attributed this finding to the characteristics of the colostrum and to the technique.

Table 2. Mean and standard deviation of immunoglobulins in blood serum of Canchim-Nelore calves born to primiparous (B1) and multiparous (B2) cows before colostrum intake $(0)$ and after $1,2,7,15$, and 30 days of life

\begin{tabular}{|c|c|c|c|c|c|c|}
\hline \multirow[t]{2}{*}{ Group } & \multicolumn{6}{|c|}{ Moments (days) } \\
\hline & 0 & 1 & 2 & 7 & 15 & 30 \\
\hline & \multicolumn{6}{|c|}{ Immunoglobulin $\mathrm{A}(\mathrm{mg} / \mathrm{dL})$} \\
\hline B1 & $84.4 \pm 12.7 \mathrm{Ab}$ & $259 \pm 105 \mathrm{Aa}$ & $269 \pm 100 \mathrm{Aa}$ & $313 \pm 169 \mathrm{Ba}$ & $336 \pm 148 \mathrm{Aa}$ & $277 \pm 106 \mathrm{Ba}$ \\
\hline \multirow[t]{2}{*}{ B2 } & $84.6 \pm 15.6 \mathrm{Ac}$ & $322 \pm 115 \mathrm{Ab}$ & $307 \pm 116 \mathrm{Ab}$ & $411 \pm 134$ Aa & $423 \pm 133 \mathrm{Aa}$ & $374 \pm 111 \mathrm{Aab}$ \\
\hline & \multicolumn{6}{|c|}{ Heavy chain immunoglobulin $\mathrm{G}$ (mg/dL) } \\
\hline B1 & $417 \pm 231$ Ad & $1,692 \pm 342 \mathrm{Aa}$ & $1,628 \pm 286 \mathrm{Aa}$ & $1,313 \pm 697 \mathrm{Ab}$ & $826 \pm 184 \mathrm{Ac}$ & $594 \pm 109$ Acd \\
\hline B2 & $402 \pm 268 \mathrm{Ad}$ & $1,866 \pm 512 \mathrm{Aa}$ & $1,812 \pm 450 \mathrm{Aa}$ & $1,287 \pm 334 \mathrm{Ab}$ & $920 \pm 233 \mathrm{Ac}$ & $650 \pm 135$ Acd \\
\hline & \multicolumn{6}{|c|}{ Light chain immunoglobulin G (mg/dL) } \\
\hline B1 & $3.31 \pm 3.18 \mathrm{Ad}$ & $959 \pm 359 \mathrm{Aa}$ & $922 \pm 376 \mathrm{Aa}$ & $722 \pm 332 \mathrm{Aab}$ & $482 \pm 162 \mathrm{Abc}$ & $323 \pm 104 \mathrm{Ac}$ \\
\hline B2 & $8.73 \pm 9.59 \mathrm{Ad}$ & $1,053 \pm 616 \mathrm{Aa}$ & $1,010 \pm 607 \mathrm{Aa}$ & $722 \pm 368 \mathrm{Ab}$ & $562 \pm 247 \mathrm{Abc}$ & $384 \pm 142$ Ac \\
\hline \multicolumn{7}{|c|}{ Total immunoglobulin G (mg/dL) } \\
\hline B1 & $420 \pm 232 \mathrm{Ad}$ & $2,651 \pm 624 \mathrm{Aa}$ & $2,550 \pm 587 \mathrm{Aa}$ & $2,035 \pm 995 \mathrm{Ab}$ & $1,308 \pm 334 \mathrm{Ac}$ & $917 \pm 194 \mathrm{Ac}$ \\
\hline B2 & $410 \pm 267 \mathrm{Ad}$ & $2,918 \pm 852 \mathrm{Aa}$ & $2,822 \pm 865 \mathrm{Aa}$ & $2,010 \pm 580 \mathrm{Ab}$ & $1,483 \pm 422 \mathrm{Ac}$ & $1,034 \pm 253 \mathrm{Ac}$ \\
\hline
\end{tabular}

Mean values followed by the same upper case letters in the same column and lower case letters on the same line do not differ significantly according to Tukey test $(\mathrm{P}<0.05)$. 
Table 3. Mean and standard deviation of mineral concentration in blood serum of Canchim-Nelore calves born to primiparous (B1) and multiparous (B2) cows before colostrum intake (0) and after $1,2,7,15$, and 30 days of life

\begin{tabular}{|c|c|c|c|c|c|c|}
\hline \multirow[t]{2}{*}{ Group } & \multicolumn{6}{|c|}{ Moments (days) } \\
\hline & 0 & 1 & 2 & 7 & 15 & 30 \\
\hline & \multicolumn{6}{|c|}{ Total calcium (mg/dL) } \\
\hline B1 & $10.7 \pm 0.67 \mathrm{Aa}$ & $10.8 \pm 0.66$ Aа & $10.6 \pm 1.32 \mathrm{Aa}$ & $11.1 \pm 0.72 \mathrm{Aa}$ & $10.6 \pm 0.92 \mathrm{Aa}$ & $10.8 \pm 0.91 \mathrm{Aa}$ \\
\hline B2 & $10.8 \pm 0.68 \mathrm{Aa}$ & $11.0 \pm 0.76 \mathrm{Aa}$ & $11.2 \pm 0.88 \mathrm{Aa}$ & $10.9 \pm 0.81 \mathrm{Aa}$ & $11.1 \pm 0.67 \mathrm{Aa}$ & $10.9 \pm 0.55 \mathrm{Aa}$ \\
\hline $\begin{array}{l}\text { B1 } \\
\text { B2 }\end{array}$ & $\begin{array}{l}1.15 \pm 0.12 \mathrm{Aa} \\
1.09 \pm 0.09 \mathrm{Aa}\end{array}$ & $\begin{array}{l}1.09 \pm 0.17 \mathrm{Aa} \\
1.10 \pm 0.09 \mathrm{Aa}\end{array}$ & $\begin{array}{l}\text { Ionized calci } \\
1.09 \pm 0.15 \mathrm{Aa} \\
1.10 \pm 0.09 \mathrm{Aa}\end{array}$ & $\begin{array}{l}n(\mathrm{mMol} / \mathrm{L}) \\
1.10 \pm 0.11 \mathrm{Aa} \\
1.07 \pm 0.11 \mathrm{Aa}\end{array}$ & $\begin{array}{l}1.08 \pm 0.14 \mathrm{Aa} \\
1.06 \pm 0.10 \mathrm{Aa}\end{array}$ & $\begin{array}{l}1.15 \pm 0.17 \mathrm{Aa} \\
1.12 \pm 0.13 \mathrm{Aa}\end{array}$ \\
\hline \multicolumn{7}{|c|}{ Inorganic phosphorus (mg/dL) } \\
\hline B1 & $6.40 \pm 0.92 \mathrm{Ad}$ & $7.51 \pm 0.89 \mathrm{Ac}$ & $7.68 \pm 0.93 \mathrm{Ac}$ & $9.41 \pm 1.22 \mathrm{Aab}$ & $9.80 \pm 0.98 \mathrm{Aa}$ & $8.86 \pm 1.36 \mathrm{Ab}$ \\
\hline B2 & $6.72 \pm 0.86 \mathrm{Ac}$ & $8.22 \pm 1.10 \mathrm{Ab}$ & $8.20 \pm 0.66 \mathrm{Ab}$ & $8.97 \pm 0.98 \mathrm{Aab}$ & $9.38 \pm 0.83 \mathrm{Aa}$ & $9.22 \pm 0.73 \mathrm{Aa}$ \\
\hline \multicolumn{7}{|c|}{ Magnesium (mg/dL) } \\
\hline B1 & $1.99 \pm 0.18 \mathrm{Abc}$ & $2.34 \pm 0.23 \mathrm{Aa}$ & $2.11 \pm 0.22 \mathrm{Ab}$ & $1.98 \pm 0.25 \mathrm{Abc}$ & $1.89 \pm 0.18 \mathrm{Ac}$ & $1.87 \pm 0.18 \mathrm{Bc}$ \\
\hline B2 & $2.06 \pm 0.25 \mathrm{Ab}$ & $2.38 \pm 0.31 \mathrm{Aa}$ & $2.07 \pm 0.21 \mathrm{Ab}$ & $2.02 \pm 0.17 \mathrm{Ab}$ & $1.98 \pm 0.16 \mathrm{Ab}$ & $2.13 \pm 0.21 \mathrm{Ab}$ \\
\hline \multicolumn{7}{|c|}{ Sodium (mMol/L) } \\
\hline B1 & $141 \pm 1.75 \mathrm{Aa}$ & $138 \pm 2.20 \mathrm{Ab}$ & $138 \pm 2.28 \mathrm{Bb}$ & $139 \pm 2.75 \mathrm{Aab}$ & $139 \pm 2.03 \mathrm{Aab}$ & $140 \pm 2.36 \mathrm{Aab}$ \\
\hline B2 & $141 \pm 3.17 \mathrm{Aa}$ & $140 \pm 4.17 \mathrm{Aa}$ & $141 \pm 2.87 \mathrm{Aa}$ & $139 \pm 2.44 \mathrm{Aa}$ & $140 \pm 2.68 \mathrm{Aa}$ & $141 \pm 0.95 \mathrm{Aa}$ \\
\hline \multicolumn{7}{|c|}{ Potassium (mMol/L) } \\
\hline B1 & $4.85 \pm 0.31 \mathrm{Ac}$ & $4.99 \pm 0.35 \mathrm{Abc}$ & $5.18 \pm 0.54 \mathrm{Aabc}$ & $5.45 \pm 0.40 \mathrm{Aa}$ & $5.52 \pm 0.44 \mathrm{Aa}$ & $5.33 \pm 0.35 \mathrm{Aab}$ \\
\hline B2 & $4.89 \pm 0.33 \mathrm{Ab}$ & $5.12 \pm 0.27 \mathrm{Aab}$ & $5.19 \pm 0.49 \mathrm{Aab}$ & $5.22 \pm 0.44 \mathrm{Aab}$ & $5.38 \pm 0.47 \mathrm{Aa}$ & $5.12 \pm 0.29 \mathrm{Aab}$ \\
\hline
\end{tabular}

Mean values followed by the same upper case letters in the same column and lower case letters on the same line do not differ significantly according to Tukey test $(\mathrm{P}<0.05)$.

The serum levels of IgA presented a strong correlation to serum concentrations of total protein $(\mathrm{r}=0.68, \mathrm{P}<0.01)$ and globulins $(\mathrm{r}=0.60, \mathrm{P}<0.01)$. Fagliari et al. (2006) reported immunoglobulin A concentrations of $258 \pm 15.1 \mathrm{mg} / \mathrm{dL}$ in healthy Holstein calves 6-12 months old. According to Kaneko et al. (2008), IgA levels in adult cattle range from 10 to $50 \mathrm{mg} / \mathrm{dL}$, which is much lower than our findings.

No differences were found in the concentrations of heavy chain IgG, light chain IgG and total IgG in the calves' serum (Table 2). Increases of 4 and 4.6-fold were found in heavy chain IgG concentrations; 290 and 121-fold in light chain IgG, and 6.31 and 7.12-fold in total IgG (groups B1 and $\mathrm{B} 2$, respectively), on day 1 when compared with day 0 (Table 2), indicating that light chain IgG levels presented the highest increase after colostrum intake by neonatal calves.

Serum concentrations of IgG 24 hours after birth were strongly correlated do GGT activity $(\mathrm{r}=0.69, \mathrm{P}<0.01)$, total protein $(\mathrm{r}=0.85, \mathrm{P}<0.01)$, and globulins $(\mathrm{r}=0.91, \mathrm{P}<0.01)$ at the same moment in time (Table 5); hence, these parameter showed a similar tendency for variation, increasing after colostrum intake. The same tendency was reported by other authors (Borges et al. 2001, Pauletti et al. 2002). Costa et al. (2008) also noted higher concentrations of gamma globulins 24 to 36 hours after birth due to the absorption of colostrum immunoglobulins. Immunoglobulin concentrations in precolostral calves are normally zero or very low; however, the presence of gamma globulins in serum is detectable just a few hours after colostrum intake. Calves that receive insufficient colostrum present a minimal increase in immunoglobulin levels in serum (Eckersall 2008), and FPIT is considered when IgG levels are below $800 \mathrm{mg} / \mathrm{dL}$ 24 hours after birth, while concentrations above $1,500 \mathrm{mg} /$ $\mathrm{dL}$ of serum IgG at that time are considered ideal for PIT
(Dewell et al. 2006, Waldner \& Rosengren 2009). In our study, all the animals reached desirable levels of serum IgG through natural suckling.

It is important to be aware of not only the role of the concentration of blood serum parameters but also the impact of management practices in the exposure of animals to potential pathogens. Management practices must be different between dairy and beef cows and its calves, since their environment in completely opposite (Feitosa et al. 2010). Beef calves are less challenged by pathogens in extensive management practices than dairy calves, that are confined (Costa et al. 2008). Feitosa et al. (2010) reported a lower serum concentration of IgG in Nelore calves when compared to Holstein calves at 24 hours of life, and that, considering only the evaluation of IgG levels, beef calves presented a lower FPIT than dairy calves at 24 hours of age. The milk yield is also important, since primiparous beef cows may produce insufficient amounts of colostrum to feed and protect their calves.

Table 4. Mean and standard deviation of enzyme activity and protein concentrations in colostrum whey of primiparous (V1) and multiparous (V2) Canchim cows immediately after parturition

\begin{tabular}{|c|c|c|}
\hline \multirow[t]{2}{*}{ Parameter } & \multicolumn{2}{|c|}{ Groups } \\
\hline & V1 & V2 \\
\hline Alkaline phosphatase (U/L) & $572 \pm 251 \mathrm{~A}$ & $646 \pm 468 \mathrm{~A}$ \\
\hline Gamma-glutamyl transferase (U/L) & $36,977 \pm 20,021 \mathrm{~A}$ & $32,044 \pm 15,130 \mathrm{~A}$ \\
\hline Total protein $(\mathrm{g} / \mathrm{dL})$ & $14.3 \pm 3.48 \mathrm{~B}$ & $16.5 \pm 2.59 \mathrm{~A}$ \\
\hline Immunoglobulin A (mg/dL) & $578 \pm 294 \mathrm{~A}$ & $666 \pm 377 \mathrm{~A}$ \\
\hline Heavy chain immunoglobulin $\mathrm{G}(\mathrm{mg} / \mathrm{dL})$ & $3,842 \pm 1,367 \mathrm{~A}$ & $4,008 \pm 1,468 \mathrm{~A}$ \\
\hline Light chain immunoglobulin G (mg/dL) & $4,046 \pm 1,279 \mathrm{~B}$ & $4,649 \pm 892 \mathrm{~A}$ \\
\hline Total immunoglobulin G (mg/dL) & $7,888 \pm 2,286 \mathrm{~A}$ & $8,657 \pm 1,795 \mathrm{~A}$ \\
\hline
\end{tabular}

* Statistically different according to Tukey test $(p>0.05)$. 
Table 5. Correlation between assessed parameters $(\mathrm{g} / \mathrm{dL})$ in blood serum of Canchim-Nelore calves at one day of age and whey of Canchim cows immediately after parturition

\begin{tabular}{lcccccc}
\hline & Total protein $^{\mathrm{S}}$ & Globulins $^{\mathrm{S}}$ & $\mathrm{GGT}^{\mathrm{S}}$ & $\mathrm{ALP}^{\mathrm{S}}$ & $\mathrm{IgG}^{\mathrm{S}}$ & Total protein $^{\mathrm{W}}$ \\
\hline Total protein $^{\mathrm{S}}$ & & $0.97^{* *}$ & $0.52^{* *}$ & $0.30^{* *}$ & & \\
GGT $^{\mathrm{S}}$ & & $0.62^{* *}$ & & & & \\
IgA $^{\mathrm{S}}$ & $0.68^{* *}$ & $0.60^{* *}$ & & & & \\
IgG $^{\mathrm{S}}$ & $0.85^{* *}$ & $0.91^{* *}$ & $0.69^{* *}$ & & & \\
Total protein $^{\mathrm{w}}$ & $0.53^{* *}$ & & & & $0.41^{*}$ & \\
IgG $^{\mathrm{W}}$ & $0.40^{*}$ & & & & & $0.70^{* *}$
\end{tabular}

${ }^{*} \mathrm{P}<0,05 ;{ }^{* *} \mathrm{P}<0,01$;

$\mathrm{S}=$ serum concentration at one day of age; $\mathrm{W}=$ whey concentration on the day of parturition.

Table 6. Results from previous studies on serum concentration of total protein, albumin, globulins, activities of gamma-glutamyl transferase, alkaline phosphatase and minerals of calves from birth to 30 days of age and adult cattle

\begin{tabular}{|c|c|c|c|c|c|c|c|}
\hline \multirow[t]{2}{*}{ Parameter } & \multirow[t]{2}{*}{ Author/year } & \multirow[t]{2}{*}{ Breed } & \multicolumn{5}{|c|}{ Moments (days) } \\
\hline & & & 1 & 2 & 7 & 15 & 30 \\
\hline \multirow[t]{6}{*}{ Total protein (g/dL) } & Fagliari et al. 1998 & Nelore & $6.07 \pm 0.73$ & - & - & $6.66 \pm 0.49$ & $6.79 \pm 0.41$ \\
\hline & Fagliari et al. 1998 & Holstein & $6.52 \pm 0.94$ & - & - & $6.65 \pm 0.87$ & $6.66 \pm 0.80$ \\
\hline & Ježek et al. 2006 & Dairy calves & $5.46 \pm 0.71$ & - & $5.37 \pm 0.52$ & $5.38 \pm 0.54$ & $5.38 \pm 0.37$ \\
\hline & Rizzoli et al. 2006 & Holstein & $6.92 \pm 0.91$ & $6.95 \pm 1.05$ & - & $6.17 \pm 0.79$ & $5.89 \pm 0.82$ \\
\hline & Kaneko et al. 2008 & Adult cattle & $6.74-7.46$ & & & & \\
\hline & Piccione et al. 2010 & Limousin & $5.77 \pm 1.11$ & $6.53 \pm 1.20$ & $5.37 \pm 0.72$ & $5.96 \pm 1.28$ & $5.56 \pm 0.82$ \\
\hline \multirow[t]{3}{*}{ Albumin $(\mathrm{g} / \mathrm{dL})$} & Ježek et al. 2006 & Dairy calves & $2.65 \pm 0.16$ & - & $2.94 \pm 0.23$ & $3.09 \pm 0.19$ & $3.22 \pm 0.19$ \\
\hline & Rizzoli et al. 2006 & Holstein & $2.12 \pm 0.23$ & $2.23 \pm 0.27$ & - & $2.34 \pm 0.28$ & $2.37 \pm 0.22$ \\
\hline & Kaneko et al. 2008 & Adult cattle & $3.03-3.55$ & & & & \\
\hline \multirow[t]{3}{*}{ Globulin (g/dL) } & Fagliari et al. 1998 & Nelore & $3.38 \pm 0.48$ & - & - & $3.92 \pm 0.37$ & $4.03 \pm 0.37$ \\
\hline & Fagliari et al. 1998 & Holstein & $3.93 \pm 0.69$ & - & - & $4.02 \pm 0.66$ & $3.96 \pm 0.56$ \\
\hline & Kaneko et al. 2008 & Adult cattle & $3.00-3.48$ & & & & \\
\hline \multirow[t]{2}{*}{$\operatorname{ALP}(U / L)$} & Fagliari et al. 1998 & Nelore & $440 \pm 132$ & - & - & $357 \pm 107$ & $281 \pm 93.0$ \\
\hline & Fagliari et al. 1998 & Holstein & $416 \pm 115$ & - & - & $338 \pm 101$ & $280 \pm 75.4$ \\
\hline \multirow[t]{4}{*}{ GGT (U/L) } & Fagliari et al. 1998 & Nelore & $718 \pm 215$ & - & - & $199 \pm 81.0$ & $46.6 \pm 13.0$ \\
\hline & Fagliari et al. 1998 & Holstein & $790 \pm 296$ & - & - & $180 \pm 73.3$ & $43.3 \pm 15.0$ \\
\hline & Ježek et al. 2006 & Dairy calves & $469 \pm 416$ & - & $104 \pm 78$ & $54 \pm 36$ & $34 \pm 19$ \\
\hline & Kaneko et al. 2008 & Adult cattle & $6.1-17.4$ & & & & \\
\hline \multirow[t]{3}{*}{ Total Calcium (mg/dL) } & Ježek et al. 2006 & Dairy calves & $11.6 \pm 1.12$ & - & $10.5 \pm 0.68$ & $10.0 \pm 0.8$ & $10.2 \pm 0.72$ \\
\hline & Rizzoli et al. 2006 & Holstein & $11.0 \pm 1.09$ & $10.6 \pm 0.98$ & - & $9.75 \pm 1.00$ & $10.32 \pm 0.86$ \\
\hline & Kaneko et al. 2008 & Adult cattle & $9.7-12.4$ & & & & \\
\hline \multirow[t]{6}{*}{ Inorganic phosphate (mg/dL) } & Fagliari et al. 1998 & Nelore & $6.85 \pm 0.83$ & - & - & $6.90 \pm 1.01$ & $6.38 \pm 1.09$ \\
\hline & Fagliari et al. 1998 & Holstein & $6.57 \pm 0.98$ & - & - & $6.66 \pm 0.95$ & $6.20 \pm 0.99$ \\
\hline & Ježek et al. 2006 & Dairy calves & $8.27 \pm 1.15$ & - & $9.72 \pm 0.99$ & $9.32 \pm 0.93$ & $8.85 \pm 0.96$ \\
\hline & Rizzoli et al. 2006 & Holstein & $7.12 \pm 0.94$ & $7.86 \pm 0.87$ & - & $8.53 \pm 1.00$ & $7.95 \pm 0.85$ \\
\hline & Kaneko et al. 2008 & Adult cattle & $5.6-6.5$ & & & & \\
\hline & Piccione et al. 2010 & Limousin & $6.28 \pm 0.87$ & $8.23 \pm 1.05$ & $10.4 \pm 1.3$ & $10.7 \pm 1.08$ & $12.1 \pm 1.18$ \\
\hline \multirow[t]{3}{*}{ Magnesium (mg/dL) } & Fagliari et al. 1998 & Nelore & $2.22 \pm 0.19$ & - & - & $2.47 \pm 0.20$ & $2.30 \pm 0.16$ \\
\hline & Fagliari et al. 1998 & Holstein & $2.24 \pm 0.28$ & - & - & $2.28 \pm 0.25$ & $2.24 \pm 0.22$ \\
\hline & Piccione et al. 2010 & Limousin & $1.80 \pm 0.02$ & $1.75 \pm 0.02$ & $1.82 \pm 0.02$ & $1.80 \pm 0.02$ & $1.80 \pm 0.02$ \\
\hline \multirow[t]{3}{*}{ Sodium (mmol/L) } & Ježek et al. 2006 & Dairy calves & $142 \pm 3.09$ & - & $143 \pm 2.97$ & $145 \pm 2.28$ & $145 \pm 2.21$ \\
\hline & Kaneko et al. 2008 & Adult cattle & $132-152$ & & & & \\
\hline & Piccione et al. 2010 & Limousin & $132 \pm 2.48$ & $135 \pm 3.58$ & $136 \pm 5.31$ & $136 \pm 3.37$ & $133 \pm 4.56$ \\
\hline \multirow[t]{3}{*}{ Potassium (mmol/L) } & Ježek et al. 2006 & Dairy calves & $5.56 \pm 0.56$ & - & $6.52 \pm 0.64$ & $6.41 \pm 0.63$ & $6.22 \pm 0.52$ \\
\hline & Kaneko et al. 2008 & Adult cattle & $3.9-5.8$ & & & & \\
\hline & Piccione et al. 2010 & Limousin & $7.51 \pm 0.56$ & $9.71 \pm 1.52$ & $7.68 \pm 0.60$ & $7.63 \pm 0.33$ & $8.74 \pm 0.57$ \\
\hline
\end{tabular}

Heavy chain IgG and total IgG concentrations in colostrum whey did not differ between groups V1 and V2; however, light chain IgG levels were higher in V2 cows (Table 4). IgG concentrations in the colostrum whey of both groups were higher than reported by Kehoe et al. (2007) in the colostrum of Holstein cows.

Sant'Ana (2004) reported influence of lactation number in immunoglobulin concentrations in colostrum, with first lactation cows presenting an intermediate level of immunoglobulins, second lactation cows presenting lower values and cows of four or more lactations presenting higher values. In our study, the influence of lactation number on immunoglobulin concentration was significant only for light chain IgG concentration, which was higher in multiparous cows.

Total IgG concentrations in colostrum whey of cows on the day of parturition presented a medium correlation with 
total protein in the blood serum of calves 24 hours after birth $(\mathrm{r}=0.40 ; \mathrm{P}<0.05)$ and a strong correlation with total protein $(\mathrm{r}=0.70 ; \mathrm{P}<0.01)$ in colostrum whey, respectively (Table 5). This indicates that the rise in total protein concentration in calves' serum is due to intake of colostral proteins, remarkably immunoglobulin G.

No differences were found in the serum levels of total calcium and ionized calcium between groups B1 and B2 or moments (Table 3). However, although total calcium concentrations in serum remained within the reference range of values for adult cattle (Kaneko et al. 2008) (Table 6), ionized calcium levels were below the reference for this species (Kaneko et al. 2008).

Serum inorganic phosphorus concentrations from birth to 30 days old (Table 3 ) were higher than those reported by Fagliari et al. (1998) in Holstein and Nelore calves (Table 6). The serum inorganic phosphorus levels in groups B1 and B2 were higher than the reference values in adult cattle (Kaneko et al. 2008) (Table 6). According to Rosol \& Capen (1997), this is due to the action of growth hormone, which is highly active in young animals and increases the renal absorption of inorganic phosphorus.

Serum magnesium levels increased after colostrum intake in both groups B1 and B2 (Table 3), but remained within the range of reference values for cattle (Kaneko et al. 2008) (Table 6) throughout the experimental period. Fagliari et al. (1998) and Piccione et al. (2010) found no age-related influence in magnesium concentrations during the first month of life in Nelore and Holstein, and Limousin calves, respectively.

Serum sodium concentrations (Table 3) in B1 calves varied in the first month of life, with the highest values found on day 0 and the lowest on day 2, while group B2 presented no differences between moments. The absence of an age-related factor influencing sodium concentrations, as found in calves born to multiparous cows, was also reported by Piccione et al. (2010) (Table 6). Potassium levels remained within the reference range for cattle throughout the experimental period (Kaneko et al. 2008) (Table 6) and there were no differences between groups (Table 3). Age was found to influence the serum concentrations of potassium in the first month of life, unlike the findings of Piccione et al. (2010) (Table 6), who reported higher levels of potassium than we found in our study.

\section{CONCLUSION}

Based on our findings, it can be concluded that despite the differences in serum parameters between calves born to primiparous and multiparous cows, passive immunity transfer was satisfactory in all the calves of both experimental groups.

Acknowledgement.- To FAPESP (Brazil) for the financial support and scholarships granted.

\section{REFERENCES}

Barrington G.M. \& Parish S.M. 2001. Bovine neonatal immunology. Vet. Clin. Food Anim. 17:463-476.

Barrington G.M., Gay J.M. \& Evermann J.F. 2002. Biosecurity for neonatal gastrointestinal diseases. Vet. Clin. Food Anim. 18:7-34.
Besser T.E. \& Gay C.C. 1994. The importance of colostrum to the health of the neonatal calf. Vet. Clin. Food Anim. 10:107-117.

Borges A.S., Feitosa F.L.F., Benesi F.J., Birgel E.H. \& Mendes L.C.N. 2001. Influência da forma de administração e da quantidade fornecida de colostro sobre a concentração de proteína total e de suas frações eletroforéticas no soro sangüíneo de bezerros da raça Holandesa. Arq. Bras. Med. Vet. Zootec. 53:629-634.

Callan R.J. \& Garry F.B. 2002. Biosecurity and bovine respiratory disease. Vet. Clin. Food Anim. 18:57-77.

Costa M.C., Flaiban K.K.M.C., Coneglian M.M., Feitosa F.L.F., Balarin M.R.S. \& Lisbôa J.A.N. 2008. Transferência de imunidade passiva em bezerros das raças Nelore e Limousin e proteinograma sérico nos primeiros quatro meses de vida. Pesq. Vet. Bras._28:410-416.

Dewell R.D., Hungerford L.L., Keen J.E., Laegreid W.W., Griffin D.D., Rupp G.P. \& Grotelueschen D.M. 2006. Association of neonatal serum immunoglobulin G1 concentration with health and performance in beef calves. J. Am. Vet. Med. Assoc._228:914-921.

Dirksen G., Gründer H.D., Stöber M. 1993. Exame clínico dos bovinos. 3aㅗ ed., Guanabara Koogan, Rio de Janeiro. 419p.

Eckersall P.D. 2008. Proteins, proteomics, and the dysproteinemias, p.117155. In: Kaneko J.J., Harvey J.W. \& Bruss M.L. (Eds), Clinical Biochemistry of Domestic Animals. $6^{\text {th }}$ ed. Academic Press, San Diego.

Fagliari J.J., Lucas A., Ferreira Neto J.M. \& Oliveira J.A. 1986. Quadro seroproteico de bezerros submetidos a 3 sistemas e imunização contra paratifo. Arq. Bras. Med. Vet. Zootec. 38:665-683.

Fagliari J.J., Oliveira E.C., Pegorer M.F., Ferrante Junior L.C. \& Campos Filho E. 1996. Relação entre o nível sérico de gamaglobulinas e as atividades de gamaglutamiltransferase, fosfatase alcalina e aspartato aminotransferase de bezerros recém-nascidos. Arq. Bras. Med. Vet. Zootec._48:105112.

Fagliari J.J., Santana A.E., Lucas F.A., Campos Filho E. \& Curi P.R. 1998. Constituintes sanguíneos de bovinos recém-nascidos das raças Nelore (Bos indicus) e Holandesa (Bos taurus) e de bubalinos (Bubalus bubalis) da raça Murrah. Arq. Bras. Med. Vet. Zootec. 50:253-262.

Fagliari J.J., Rizzolli F.W. \& Silva D.G. 2006. Proteinograma sérico de bezerros recém-nascidos da raça Holandesa obtido por eletroforese em gel de poliacrilamida. Arq. Bras. Med. Vet. Zootec.57:1-4.

Feitosa F.L.F., Birgel E.H., Mirandola R.M.S. \& Perri S.H.V. 2001. Diagnóstico de falha de transferência de imunidade passiva em bezerros através da determinação de proteína total e de suas frações eletroforéticas, imunoglobulinas G e M e da atividade da gamaglutamiltransferase no soro sangüíneo. Ciência Rural_31:251-255.

Feitosa F.L.F., Camargo D.G., Yanaka R., Mendes L.C.N., Peiró J.R., Bovino F., Lisboa J.A.N., Perri S.H.V. \& Gasparelli E.R.F. 2010. Índices de falha de transferência de imunidade passive (FTIP) em bezerros holandeses e nelores, às 24 e 48 horas de vida: valores de proteína total, de gamaglobulina, de imunoglobulina $\mathrm{G}$ e da atividade sérica de gamaglutamiltransferase, para o diagnóstico de FTIP. Pesq. Vet. Bras. 30:696-704.

Godden S. 2008. Colostrum management for dairy calves. Vet. Clin. Food Anim. 24:19-39.

Guy M.A., McFadden T.B., Cockrell D.C. \& Besser T.E. 1994. Regulation of colostrum formation in beef and dairy cows. J. Dairy Sci. 77:3002-3007.

Hoffmann W.E. \& Solter P.F. 2008. Diagnostic enzymology of domestic animals, p.351-378. In: Kaneko J.J., Harvey J.W. \& Bruss M.L. (Eds), Clinical Biochemistry of Domestic Animals. ${ }^{\text {th }}$ ed. Academic Press, San Diego.

Hurley W.L. 2003. Immunoglobulins in mammary secretions, Vol.1 - Proteins, p.421-447. In: Fox P.F. \& McSweeney P.H.L. (Eds), Advanced Dairy Chemistry. $3^{\text {rd }}$ ed. Kluwer Academic, New York.

Ježek J., Klopčič M. \& Klinkon M. 2006. Influence of age on biochemical parameters in calves. Bull. Vet. Inst. Pulawy 50:211-214.

Kaneko J.J., Harvey J.W. \& Bruss M.L. 2008. Clinical Biochemestry of Domestic Animals. $6^{\text {th }}$ ed. Academic Press, San Diego. 916p.

Kehoe S.I., Jayarao B.M. \& Heinrichs A.J. 2007. A survey of bovine colostrum composition and colostrum management practices on Pennsylvania dairy farms. J. Dairy Sci. 90:4108-4116. 
Knowles T.G., Edwards J.E., Bazeley K.J., Brown S.N., Butterworth A. \& Warriss P.D. 2000. Changes in the blood biochemical and haematological profile of neonatal calves with age. Vet. Rec. 147: 593-598.

Kurz M.M. \& Willett L.B. 1991. Carbohydrate, enzyme, and hematology dynamics in newborn calves. J. Dairy Sci. 74:2109-2118.

Laemmli U.K. 1970. Cleavage of structural proteins during the assembly of the head of bacteriophage $\mathrm{T}_{4}$. Nature 227:680-685.

Pauletti P., Machado Neto R., Packer I.U. \& Bessi R. 2002. Avaliação de níveis séricos de imunoglobulina, proteína e o desempenho de bezerras da raça Holandesa. Pesq. Agropec. Bras. 37:89-94.

Piccione G., Casella S., Pennisi P., Giannetto C., Costa A. \& Caola G. 2010. Monitoring of physiological and blood parameters during perinatal and neonatal period in calves. Arq. Bras. Med. Vet. Zootec. 62:1-12.

Pritchett L.C., Gay C.C., Besser T.E. \& Hancock D.D. 1991. Management and production factors influencing IgG1 concentration in colostrum from Holstein cows. J. Dairy Sci. 74:2336-2341.

Radostits O.M., Gay G.C., Blood D.C. \& Hinchcliff K.W. 2007. Clínica Veterinária: Um tratado de doenças dos bovinos, ovinos, suínos, caprinos e equinos. 9ª ed. Guanabara Koogan, Rio de Janeiro. 1737p.

Rizzoli F.W., Fagliari J.J., Silva D.G., Silva S.L. \& Jorge R.L.N. 2006. Proteinograma e teores séricos de cálcio, fósforo, magnésio e ferro de bezerros recém-nascidos que mamaram colostro diretamente na vaca ou em mamadeira. Ars Vet. 22:198-202.
Rosol T.J. \& Capen C.C. 1997. Calcium regulating hormones and diseases of abnormal mineral (calcium, phosphorus, magnesium) metabolism, p.619-702. In: Kaneko J.J., Harvey J.W. \& Bruss M.L. (Eds), Clinical Biochemistry of Domestic Animals. $5^{\text {th }}$ ed. Academic Press, San Diego.

Russel K.E. \& Roussel A.J. 2007. Evaluation of the ruminant serum chemistry profile. Vet. Clin. Food Anim._23:403-426.

Sant'Ana V.A.C. 2004. Proteinograma do leite de vacas: padrões e variabilidade. Tese de Doutorado em Medicina Veterinária, Universidade de São Paulo, São Paulo, SP. 161p.

Zanker I.A., Hammon H.M. \& Blum J.W. 2001. Activities of $\gamma$-glutamyl transferase, alkaline phosphatase and aspartate-aminotransferase in colostrum, milk and blood plasma of calves fed first colostrum at $0 \pm 2,6 \pm 7$, $12 \pm 13$ and $24 \pm 25$ h after birth. J. Vet. Med. A., Physiol. Pathol. Clin. Med. 48:179-185.

Zar J.H. 1999. Biostatistical Analysis. $4^{\text {th }}$ ed. Prentice-Hall, New Jersey. 930p.

Zarcula S., Cernescu H., Mircu C., Tulcan C., Morvay A., Baul S. \& Popovici D. 2010. Influence of breed, parity and food intake on chemical composition of first colostrum in cow. Anim. Sci. Biotech. 43:154-157.

Waldner C.L. \& Rosengren L.B. 2009. Factors associated with serum immunoglobulin levels in beef calves from Alberta and Saskatchewan and association between passive transfer and health outcomes. Can. Vet. J. 50:275-281. 